\title{
Price volatility and risk management: the case of rice in the EU
}

\begin{abstract}
Alessandro Banterle $^{1 *}$, Daniela Vandone ${ }^{1}$
${ }^{1}$ University of Milan, Italy

Summary: The paper aims at analysing rice-price volatility over the last ten years, and at identifying strengths and weaknesses of financial-risk management tools other than derivatives. In particular, it focuses on innovative insurance products, like revenue insurance products, and on their potential use in agriculture. Focus will be on EU Mediterranean countries, specifically on Italy, that is the main rice producer in this area. In Europe, the Common Agricultural Policy (CAP) provides risk management tools. For example, the income stabilization tool is a measure to manage income risks. Despite this, it is still not adopted. Our analysis is a first endeavour to emphasize the most relevant issues in creating revenue insurance products for rice farmers in the EU, with focus on the Italian market.
\end{abstract}

Keywords: Agricultural commodity price volatility, rice price volatility, risk management, revenue insurance

JEL codes: Q02, Q13, Q14

Type: Article - Submitted: 11/02/2018 - Accepted: 13/07/2019

* Corresponding author: Alessandro Banterle, Full Professor. Dipartimento di Scienze e Politiche Ambientali - Università degli Studi di Milano - Via Celoria 2 - 20133 MILANO - Italy. E-mail: alessandro.banterle@unimi.it 


\section{Introduction}

During the last decades, agricultural commodity prices have significantly become more volatile. The reasons of such trend include the economic growth of developing economies, which has increased the global food demand, an inadequate and changeable supply caused by climate conditions, and financial markets speculation (Karyotis and Alijani, 2016; Adams and Gluck, 2015; Pinstrup-Anderson, 2015; Olson et al., 2014; Headey, 2011).

Farmers are price takers due to the specific nature of the product, that is a commodity, and to the small size of farms. Therefore, farmers undergo world and local price dynamics and they are not able to influence them (Tomek and Kaiser, 2014).

Past literature shows that farmers are risk averse (Hellerstein et al. , 2013; Menapace et al., 2013; Aimin, 2010) and adopt risk management strategies to cope with price risk. Price risk management options can be grouped into three categories: spot-market strategies, such as diversifying the timing of sales of annually produced crops (self-insurance); the use of forward and deferred-pricing contracts or hedging via standardized futures and options contracts; yield or revenue insurance products (Williams and Smith, 1997). The first determines risk retention and exposes farmers to the risk of too much stress on their cash flow; conversely, the second and the third one implies risk hedging or risk transfer via financial products.

Among agricultural commodities, rice presents some peculiarities that make the analysis of its market interesting, both from the socio-economic and the financial perspective. From the socioeconomic standpoint, rice is the main staple food for a great part of the population in Asia, especially in China and India. Rice cultivation generates also positive externalities for the environment: in Italy, for example, paddy fields are the habitat for amphibious, like frogs, toads and tree frogs, insects and crustaceans, aquatic birds, especially for herons and ducks (Bogliani, 2008). At the global level, rice trade accounts for $6 \%$ of total production and such volume is considered "thin", even though it is growing in recent years (FAO, 2018).

From the financial perspective, the market of rice is characterized by quite strong price volatility (FAO, 2018). Protection against price risk for rice producers faces problems. Indeed, the trade of rice on futures market started only in 1994 and the use of derivative contracts is still limited in comparison to other important agricultural commodities. In addition, the volume of rice traded on 
futures market is smaller than that of relevant agricultural products, like corn, wheat and soybean, due to the small volume of rice traded in general.

Our analysis is mostly focused on the European Union (EU). EU is a rice net importer (European Commission, 2018). Domestic production of rice is too small for a worthwhile use of futures contracts in the international trading, and the production can suffer standardization problems. Rice is cultivated in the South part of Europe, especially in Italy, where it represents about $50 \%$ of all European rice production (Fusi et al., 2014). Moreover, the rice European market is highly segmented due to several varieties with different level of prices.

Therefore, producers may not be able to utilize existing international commodities exchanges for hedging purposes, while insurance products may assume a relevant role as risk management tools.

The paper aims to identify strengths and weaknesses of financial risk management tools other than derivatives in the case of EU rice market. We focus on innovative insurance products and their potential use in the Europe.

To the best of our knowledge, this is the first analysis of risk management tools and insurance schemes for the European rice market. The focus is especially on the Italian market, which has been characterized by high levels of volatility in the last few years. The analysis contributes to shed light on the main relevant issues and criticalities that policy makers may face in establishing revenue insurance products for rice farmers aimed at managing the down side risk of rice price volatility and stabilizing farmer income.

The paper is organized as follows. Section 1 describes the main drivers connected to agricultural price volatility, focusing on the rice market. Section 2 analyses the price risk management in agriculture. Section 3 reports the discussion of the crucial issues on the topic analysed, whereas the last part is dedicated to final remarks.

\section{Price volatility in the rice market}

\subsection{Commodity price volatility drivers}


A strong price volatility in the international market of agricultural commodities has occurred over the last decade. For example, in the case of rice, we can observe a high growth of prices over the years 2007-2008 and a decrease in the following years, with an even more remarkable decrease in 2013-2014.

A number of different and complex elements affect the trends of agricultural commodity prices that act both on the demand side and on the supply side (Headey, 2011).

On the supply side, the drivers of such trends include technical innovation in the agricultural sector that in the long-run allow a growth of the global production; on the other hand, the reduction of research and development expenditures reduces the diffusion of yield-increasing innovation. Climate conditions during the crop production period are a further factor that influence production and price dynamics, especially in the major exporting countries. Then, agricultural policies, especially in the exporting countries, can affect price trends. For example, the US and EU support to bio-fuels led to a growth of demand for non-food agricultural commodities, determining a reduction of the global agricultural supply traded in the international markets. Other factors that influence price volatility are represented by the export restrictions in exporting countries, the oil price evolution, which affects the production costs of agricultural products, and financial speculation.

On the demand side, the increasing GDP per capita in emerging national economies, like BRICS countries, and the constantly evolving dietary patterns, especially in India and China, have led to a growth of the food demand connected to animal proteins, supporting the demand for cereal at world level.

Another factor influencing the price evolution is related to the agent relationships within the supply chain (Bantele et al., 2014). In particular, the type of link between agricultural sector and food industry is crucial for the price transmission in the supply chain. Farmers are price takers, as most of the agricultural products are commodities. On the opposite, most of the processed products are differentiated and processors can be price makers. Therefore, the market power of food industry is definitively stronger than the agriculture, and this affects the way in which prices move leading to an asymmetric price transmission along the supply chain.

In the case of rice, the drivers described above explain just a side of the price volatility, since there are specific factors connected to the peculiarities of the rice supply chain. 


\subsection{Price volatility drivers for rice}

In the international market of the agricultural products, the different commodity exchanges show a specific importance for certain products. In the case of rice, the most important commodity exchange, that is considered representative for the world price trends, is the market of Bangkok (Thailand).

The drivers of world price volatility for rice can be classified in three main groups: motivations that are common to other agricultural commodities, as described before, close relation between wheat and rice price trends, and trade measures on rice at country level (Headey, 2011) .

Regarding the second point, Headey (2011) and Rezitis et al. (2015) underline the link between the price volatility of wheat and that of rice. When the price of wheat in the international market is high, importing countries resort to a possible substitution between wheat and rice. This leads to an increasing demand for rice instead of wheat, which can influence the international price level (Headey 2011; Rezitis et al., 2015).

About trade measures, import and export restrictions implemented by some countries in periods of strong price volatility affect the world market, determining a variation of available supply, affecting the international rice price market. In the last years, many trade measures have occurred. For example, in 2017 Philippines applied an import restriction on rice ${ }^{1}$, in June 2018 Egypt's government announced to import rice to sustain its domestic demand, while rice exports remain prohibited. On the opposite, Saudi Arabia and Nigeria implemented import subsidy.

Figure 1 reports rice price trend over the period 2007-2017. The graph shows the strong rice price volatility in the last ten years. The peak reached in 2008 corresponds to the world rice market crisis of 2007-2008, when world rice market price tripled in less than six months. This huge price increase was mainly caused by policy decisions taken by both exporting and importing countries after the increasing pricing on other agricultural markets, like maize, wheat and soybean. A number of factors affected the increasing pricing in the above-mentioned markets such as the oil crisis, the biofuel mandates and tariffs, and a weak US dollar (Dawe, 2010).

\footnotetext{
${ }^{1}$ The National Food Authority is the unique rice importer and private grain dealers must obtain an import clearance to be allowed to import rice.
} 


\section{FIGURE 1}

The effects of price volatility are very strong in developing countries, both on those importing and exporting, worsening poverty conditions. Rice is a staple food consumed all around the word, in particular among poorest countries in Asia and Africa. Its high price volatility strongly affects consumers' purchasing power: when the price is volatile and high, consumers must spend most of their income to buy rice, and the number of undernourished people increases. On the contrary, when the price is more stable, higher food security and poverty reduction can be achieved. This happened for example in Myanmar, where in 2004 the government restricted export to stabilize rice price (World Bank, 2014).

Korhner and Kalkhul (2013) identified several factors that affected food price volatility, and specifically rice, in developing countries. According to the authors, domestic price volatility depends on the season, the production shortfalls due to weather and soil conditions, stocks, transaction costs, governmental policies, and political stability. Moreover, the international market affects the domestic one, and consequently it influences the internal price volatility of a specific country (Kornher \& Kalkuhl, 2013).

In the EU, during the past decades, the rice price trends have been strongly affected by the price policy of the Common Agricultural Policy (CAP). Until 2003-2004, the common market organization for rice (Regulation 372/95) fixed the intervention price at 298.35 Euro/t, providing a direct payment equal to 318.01 Euro/he. A maximum surface was established for each European country. In Italy, for example, it was 239.259 he. This policy, oriented to price support, allowed stabilizing the price trends in the EU rice market until the beginning of 2000s.

In 2003, the new regulations 1782 and 1785 strongly reduced the intervention price to 150 Euro/t lowering the European price to the same level of the world one. Moreover, the maximum surface was reduced too (in Italy, 219,588 he). To compensate rice farmers for the profitability reduction a new direct payment was introduced, divided in a decoupled aid (in Italy, 616 Euro/he) and a coupled aid (453 Euro/he).

With the health check of the CAP the decoupled aid has been incorporated into the overall farm payment, and in 2012 also the coupled aid was included in the overall farm payment. Therefore, 
crop-specific payment for rice has been abolished since 2012, and since 2004 the intervention price does not influence anymore in a strong way the price rice trends in the EU.

Moreover, the reforms of the European policy for rice, in line with the reforms of the CAP, led to a reduction of tariffs for imports, in order to favor developing countries. Specifically, until the end of 2018, the European Union imported zero-duty rice from Cambodia and Myanmar in view of the Everything but Arms (EBA) trade scheme (Regulation EU 978/2012), but this harmed European rice growers and fostered price volatility on the European market. In January 2019, after rice growers' remonstration, EU imposed safeguard measures on rice from Cambodia and Myanmar rice imports (Regulation EU 2019/67), in order to try to protect European rice producers (European Commission 2019).

The EU adopted a specific regulation for rice because of its peculiarity, namely, specific soil and cultivation practices. Then, rice cultivation is important for maintaining the wetlands' agroenvironmental equilibrium and the wetlands' biodiversity. In an initial phase, the price of rice was high and quite stable due to the price support guaranteed to rice growers by the EU. After the intervention price reduction of 2003, the rice price volatility started to increase. However, profitability losses of for farmers were partly compensated by CAP direct payment. After 2012, namely after that the decoupled aid was incorporated into the direct payment, rice production has been not more directly sustained, and production decisions have been taken by farmers by only taking in consideration the market conditions. Despite the increased price volatility, farmers produce rice because of market conditions and the particularly suited area in which they are located.

In Europe, for example, the highest rice cultivation area was reached in 2010 and 2011, when approximately 477,000 hectares were devoted to rice production. On the contrary, the lowest rice production area was approximately 414,000 hectares in 2015 (European Commission, 2015). More specifically in Italy, which is the leading rice production country in Europe, the rice cultivations slightly changed from 2005 to 2015, reaching a peak in 2010 and 2011 (247,000 hectares), it then decreased in 2013 (216,000 hectares) but then it remained quite stable around 225,000 hectares in the remaining years (Ente Nazionale Risi, 2015).

Even the Italian domestic rice market during the last decade was characterized by a strong price volatility. More in detail, Figure 2 and 3 illustrate the price volatility both for paddy and milled rice 
in Italy from 2007 to 2017 . The graphs report the price trends of some varieties traded in the Italian rice market: three are varieties belonging to the Japonica rice (Arborio, Loto, and Balilla) and one is a variety belonging to the Indica rice (Thaibonnet). The graphs remark the high volatility during the last ten years, both for paddy rice and milled rice. Trends were similar for both products, and we can see that the first peak was in line with the world rice crisis of $2007 / 2008$, while those following reflected the market and production conditions. Specifically, a strong volatility is revealed in the case of the Arborio variety. This kind of rice is a high quality product, it is particularly appreciated from Italian consumers, and its production is quite limited. On the opposite, the level of prices for Balilla and Thaibonnet varieties are lower.

Internal price volatility was caused by several factors: the international rice price volatility and the relative drivers; the EU trade agreements with developing countries; climate conditions; and a slight change in consumers' behaviours (Ente Nazionale Risi, 2017).

FIGURES 2 AND 3

\section{Price risk management in agriculture}

\subsection{General issues}

Price risk uncertainty is a relevant problem in all business activities including agricultural commodities, whose price volatility has been relevant in the last decades.

Price risk can be defined as the difference between the expected price and the actual price of the commodity; among others, major sources of price risks are stock levels, climate conditions, financial commodity markets speculation, demand/supply imbalance, market imperfections (Pinstrup-Anderson 2015; Tomek and Kaiser 2014; Peri et al., 2014; Baldi et al., 2016).

Price risk is essentially the result of price uncertainty and affects producers when they make production and marketing decisions regarding application of inputs and labour on the basis of price they expect to receive after harvest, which may be different from the actual price.

Producers are normally concerned about the downside risk, which is the risk that the actual price is lower than the expected price; prices for the products may be so uncertain that what appear profitable when planted ends up unprofitable due to price decreases in the following months. However, farmers are also affected by the upside risk: if the actual price is higher than the expected 
price, they may have lost the opportunity of higher production and higher income. In both cases, price volatility can adversely affect farm profitability (Dick and Wang 2010; Pasaribu 2010; Le Clech and Fillat-Castejón 2017). Consequently, for farmers' risk management tools are increasingly important.

Literature is unanimous in considering that farmers are risk-averse, and self-insurance is generally limited since most producers simply have too much stress on their cash flow. Conversely, price risk management through financial products can benefit farmers with relevant rise in output (Mahul and Vermersch 2000; Machnes and Wong 2003; Hau 2006; Lence 2009). Hedging has also a positive impact on access to credit and on the financial cost of the farm's debt that is the risk premium the producer has to pay to its lenders, i.e. banks (Buhl et al., 2009). Moreover, price risk management allows farmers to reach a more sophisticated planning horizon, to plan their expenditures and activities, and to decide on eventual investments (Aimin, 2010; Buhl et al., 2009; Grinblatt and Titman, 2002).

Financial instruments utilized to hedge commodities price risk can be grouped into two categories, derivatives instruments, which include forward contracts, futures contracts, options ${ }^{2}$, and insurance products.

Forward and futures contracts are an agreement between two parties to buy or sell the underlying asset, i.e. the commodity, at a certain time in the future for a certain price. Hedging via forward and futures market can control price risk; however, while it ensures the producer against price reduction, it does not allow enjoying price increases. Conversely, options allow the producer insuring prices against declines, while taking advantage of price increases. Indeed, the buyer of the option has the opportunity, but not the obligation, to exercise the agreement. The exercise price of the put option guarantees a price insurance to producers in the form of a minimum price floor. The main cost involved in the purchase of put options is the price of the options premium, which is paid up-front. The value of the premium depends on the strike price relative to the underlying value of the options contract, the duration of the contract and the volatility of the underlying commodity market prices.

\footnotetext{
${ }^{2}$ For a deep analysis of derivatives see Hull (2006).
} 
The largest exchanges on which commodities futures and option contracts are traded are the Chicago Board of Trade (CBOT) and the Chicago Mercantile Exchange (CME).

As far as "soft commodities" - among which is rice - the China's Dalian Commodity Exchange and Shanghai Futures Exchange are the largest commodities exchanges now. Open interests and volumes have increased considerably in the past decade and even more in recent years, likely reflecting the desire of both sellers and buyers to mitigate price risk.

Insurance works as an option as well and allows the producer to transfer risk to a third party private company or government institution - versus the payment of a premium. The underlying principle of insurance lies in the law of large numbers, where the incidence of risk is distributed over individuals. In crop insurance, the losses suffered by farmers in a particular locality are borne by farmers in other areas and the reserves accumulated through premium in good years are used to pay the claims in bad years (Pasaribu 2010; He et al. 2018).

Several papers on price risk management and financial products have appeared in the agricultural economics literature. Turvey (1989) examines premium setting for revenue insurance, Babcock and Hennessy (1996) focus on the issue of moral hazard with revenue insurance and Hart et al. (2001) investigate the cost and structure of several possible livestock revenue insurance products, while Dick and Wang (2010) analyse the effect of government interventions in agricultural insurance. Tang et al. (2010) investigate the factors that affect demand of agricultural insurance and Wolf (2012) focuses on dairy farmer use of price risk management tools, specifically futures contracts and options. A specific study on rice insurance products and price risk management is Pasaribu (2010) who analyses suitable rice farm insurance schemes for the Indonesian market. More recently, Santeramo et al. (2016) and Santeramo and Ford Ramsey (2017) investigate farmer participation in the Italian insurance crop program and European crop insurance. Santeramo (2018) analyses also the effect of imperfect information in the Italian insurance market.

\subsection{Rice revenue guarantees}

As shown in the previous paragraph, there are several instruments to cope with price risk, but there are several issues connected to the use of forward and future contracts and options. 
Indeed, when a forward contract is signed, the two parties fix at time to the price at which buy and sell the harvest at time $t_{t}$. However, since forward contracts are not standardized but traded over-the-counter, the parties may fail to agree on such a price. In addition, the buyer of the forwards (i.e. the buyer of the rice) normally requires a guarantee of actual delivery of the agreed quantity. Consequently, when the crop is lower than expected the seller (i.e. the farmer) of the forward must buy the missing quantity of commodity on the market to fulfil the forward contract, at a price probably higher than the forward price at which she agreed to sell the harvest.

As far as futures and options, actual use is limited because of many reasons such as access to trading facilities and expertise required. Moreover, the rice trading on future markets started only in 1994 and rice-trading volume is low relative to futures contracts on other major agricultural products. Then, domestic prices are often not strongly related to world market prices, and trading is costly in terms of margins and option premium. In addition, compared to the US, in EU farmers produce smaller quantities of rice to take part in futures markets worthwhile and, even though aggregated across farmers, production is subject to problems of standardization and quality.

Therefore, our analysis is focused on insurance products. At the beginning of $90 \mathrm{~s}^{3}$, revenue insurance products started to be offered in the US markets. Revenue insurance products combine yield and price insurance: they offer protection against the farmer's loss of revenue both due to declines in the price of the commodity during the crops' growing season and due to loss of harvests caused by natural disasters. Thus, revenue insurance products insure the gross revenue of the crop and provide farmers with payment if the revenue falls below a threshold, both in case of yield or price losses. Their ultimate goal is to reduce year-to-year income variability (Coble et al., 2003).

The revenue guarantee is computed like an option. If the actual price multiplied by the realized yield at harvest $\left(t_{t}\right)$ is lower than the expected price multiplied by the expected yield at planting $\left(t_{0}\right)$, the farmer receives the difference; zero otherwise. The result is then multiplied by the chosen coverage level, usually from 50 to 85 percent.

\footnotetext{
3 Long time before 90s, the first type of insurance product offered to farmers has been the yield insurance product, that offers protection against the loss of crops due to meteorological events and natural disasters, such as floods, drought, hail. Yield insurance products are generally offered in the form of multi-peril crop insurance (MPCI) and cover different types of natural disasters bundled together to form a combined package. Those products do not offer protection against price volatility, thus are not the object of our study.
} 
The indemnity equation for the revenue protection (RP) can be written as:

(1)

$$
R P=\max \left[p_{0}^{*} y_{0}-p_{t}^{*} y_{t} ; 0\right] * I c_{0}
$$

Where $p_{0}$ is the expected price, $y_{0}$ is the expected farm yield at planting, $p_{t}$ is the actual price, $y_{t}$ is the realized yield at harvest, $I c_{0}$ is the chosen coverage level.

Reference prices come from futures markets: the expected price is the preseason price for the harvest month contract, while the harvest market price is the cash settlement price in the future market. The expected farm yield at planting depends on the actual production history of the farm.

The net revenue protection (NRP) is obtained by subtracting from RP the insurance cost, that is the amount of the premium paid to the insurance company:

$$
N R P=\max \left[p_{0}{ }^{*} y_{0}-p_{t}{ }^{*} y_{t} ; 0\right] * l c_{0}-i p_{0}
$$

where $i p_{0}$ is the insurance premium. Figure 4 graphically shows the relation expressed in the equation, where the $x$-axis reports the $\mathrm{p}_{\mathrm{t}}{ }^{*} \mathrm{y}_{\mathrm{t}}$ and the $\mathrm{y}$-axis the payoff (NRP). When farmers subscribe an insurance, they pay a premium to the insurance company. When $p_{t}{ }^{*} y_{t}>p_{0}{ }^{*} y_{0}$, farmers must pay the insurance premium, but they do not receive any payment from insurance company. When $\mathrm{p}_{\mathrm{t}}{ }^{*} \mathrm{y}_{\mathrm{t}}<\mathrm{p}_{0}{ }^{*} \mathrm{y}_{0}$ farmers receive the revenue protection depending on prices and yields levels at time $t$.

FIGURE 4

\section{Discussion}

In Europe, the Common Agricultural Policy includes risk management tools and the support to risk management is described in the second pillar for the period 2014-2020 (Reg. 1305/2013 art. 3639). The income stabilization tool (IST) (art. 39), which was proposed in the post-2013 reform, is a measure introduced in the Rural Development Regulation to handle income risks (Severini et al., 2018; Castañeda-Vera and Garrido, 2017; Capitanio et al., 2016). It is a mutual fund that covers farmers from income reductions. Farmers contribute to this fund in order to create a financial 
reserve that can be applied to cover income failures coming from total farm activity (that is, not just from production). The aim of the IST is to compensate major losses (i.e., those higher than $30 \%$ compared to the preceding average income) (European Commission, 2017).

IST represents a new measure for managing agricultural risks. Nowadays, the ISTs have been designed by only two countries (Italy and Hungary) and one Spanish region (Castilla y Leon) Nevertheless, because of operational difficulties, no IST has been concretely enacted yet (European Commission, 2017).

At the moment, an important example of a country offering a comprehensive crop revenue insurance at market level is the US, where the Risk Management Agency introduced the first revenue insurance product in 1996. Although a variety of coverage options are available, the three standard revenue insurance products, which mainly differ in rate setting procedures, are Crop Revenue Coverage (CRC), Income protection (IP), Revenue Assurance (RA).

Those products are offered both at firm-level and at area-level. In the first case, the threshold under which the insurance pays is defined with regards to the characteristics of the farmer's insured crop. In the second case, the threshold is selected for an area yield/revenue: if the gross revenue of a crop in a certain area is below a certain threshold, all farmers are compensated, that is all of the crops in a county are insured as a single unit ${ }^{4}$.

The US insurance system for agricultural commodities is public-private and is administered by the Risk Management Agency (RMA), a division of the USDA. The public sector subsidies $60 \%$ of premiums and co-finances losses in proportion to the severity of losses. Public reinsurance assumes between $35 \%$ and $100 \%$ of losses; the larger the losses, the more co-financing is provided. According to literature, the most crucial success factors for US revenue insurances are: co-financing of premium rates, large database of historical yields and prices, transparent and highly liquid commodity-price discovery mechanisms (Munich, 2011).

\footnotetext{
${ }^{4}$ The most widespread area-based insurance product is the Group Risk Income Protection (GRIP). According to Deng et al. (2007), some believe that this area-based insurance product provides farmers with a valuable, and less expensive, alternative to the farm-level insurance products; other thinks that the basis risk associated with area-based products makes them unattractive for most farmers. From a farmer's perspective, the choice between the area-based and farmlevel insurance products typically comes down to a trade-off between higher basis risk (with the area-based products) and higher premium cost (with the farm-level products).
} 
The importance of government support is commonly recognized in literature as a reason of failure in the agricultural insurance markets (Tang et al., 2010). Indeed, agriculture is a high-risk sector, with frequent and highly covariate agricultural production risks and the persistence of moral hazard and adverse selection problems, and insurance companies have little economic interest in engaging in it. Specifically, insurance companies face specific problems when identifying the input data to determine the level of the coverage and the amount of the premiums. As far as the yield component, in order to identify the expected farm yield at planting, it is essential to have a sufficiently long time series of data, both at firm-level and at area-level. The same holds for measuring the expected variations of futures prices between planting and harvesting.

A time series of at least 20 years is only available for a few markets, like CBOT in the US. Regional markets, such as the Italian one could use global markets as a proxy, but this works only if there is a high correlation between local and global commodity prices.

Without government subsidies or public reinsurance, insurers would not offer revenue insurance products or would offer them at a very expensive risk premium (Mahul and Vermersch, 2000).

\section{Conclusions}

Results show that revenue insurance products seem a dynamic field of research. They provide protection against declines in price during the crop growing season, measuring price variability with reference to a specific market benchmark.

Currently, in Italy there are no revenue insurance products available. In general, major issues in creating such market are high represented by the production costs in creating single-farm insurance products, data availability, information asymmetries, and high premium requiring public intervention.

Our analysis is a first attempt to highlight the most relevant issues in creating revenue insurance products for rice farmers in the EU, with a specific focus on the Italian market.

The localization of rice production in Italy is characterized by a strong geographical concentration in the North-West area of the country, where more than $85 \%$ of rice farms are located 
(www.enterisi.it). Rice millers and retailers are located in the same area, which allows reducing transportation costs. This geographical specificity of rice production could determine favourable conditions to develop geographically based revenue insurance products. In this way, it is possible to overcome the constrain of high production costs connected to single-farm insurance, as the farms located in this area are quite similar in terms of structural and production conditions (i.e. farm size, level of mechanization, high innovation attitude, type of soil, irrigation systems).

Concerning data availability, in Italy there are no futures contracts with rice as underlying asset. This means that it is not possible to evaluate the insurance premium based on the difference between spot and futures price trends. However, there are long time series data regarding paddy and milled rice prices deriving from local commodity exchange markets. Time series data on paddy production yields are also available. Indeed, since many years a public institution has been established to collect data for rice and to support supply chain relationship ("Ente Nazionale Risi") which provides databases on rice market. Therefore, a deep amount of data is available to design geographically based insurance revenue contracts based on rice farming specificities.

As far as information asymmetries, the characteristics of the Italian rice market may help to overcome such criticalities. In particular, adverse selection problems are pre-contractual and regard the propensity of high risky agents to subscribe insurance products. For rice the level of risk connected to price volatility is almost the same for all producers; what may differ are the production yields as they can vary due to sub-area climatic and soil conditions. This problem can be solved by applying different premium rates accordingly to the sub-area specificities. Regarding moral hazard, farmers are price takers and therefore they have not the possibility to behave in opportunistic way in case of price volatility. When prices and yields are low, the market incentives for producers could be low as well, but still exist, as the producers normally have long-run and valuable relationship with their customers in the supply chain. Therefore, even in this case moral hazard behaviours should be limited.

The most critical issue remains the high level of the premium for insurers. Public intervention can help in reducing its level, providing a specific framework in which support is provided to farmers. In this direction, new opportunities can be opened by the IST and thanks to the new coming program 
for rural development. In particular, the latter policy can include specific measures concerning public support for revenue insurance.

Overall, risk sharing by means of insurance products would help farmers to reduce uncertainty related to the future prices of their commodities with several positive spill over effects. Indeed, by pooling the risk, insurance can lower the cost to customer, producers would be able to reduce large cyclical swings, and consumers would be able to rely on less volatile prices, with a consequent increase in efficiency. Concerns may arise with regard to the size of the extreme event to be insured, as well as on market failures due to information asymmetries, which may induce opportunistic behaviours. Strong risk management practices, as well as close supervision are therefore relevant for the establishment of an effective insurance market.

\section{References}

Adams Z., \& Glück T. (2015). "Financialization in commodity markets: A passing trend or the new normal?" Journal of Banking \& Finance, 60(C), 93-111.

Aimin, H. (2010). Uncertainty, risk aversion and risk management in agriculture, farmer; uncertainty; risk aversion; risk management. Agriculture and Agricultural Science Procedia, 1(2010), 152156. http://dx.doi.org/10.1016/j.aaspro.2010.09.018.

Babcock, B.A., \& Hennessy, D.A. (1996). Input Demand under Yield and Revenue Insurance. American Journal of Agricultural Economics, 78(2), 416. doi: 10.2307/1243713.

Baldi, L., Peri, M., \& Vandone, D. (2016). Stock markets' bubbles burst and volatility spillovers in agricultural commodity markets. Research in International Business and Finance, 38(C), 277285. doi: 10.1016/j.ribaf.2016.04.020.

Bantele, A., Cavaliere, A., Carraresi, L., \& Stranieri, S. (2014). Food SMEs Face Increasing Competition in the EU Market: Marketing Management Capability Is a Tool for Becoming a Price Maker. Agribusiness, 30(2), 113-131. DOI: 10.1002/agr.21354. 
Bogliani, G. (2008). II riso. Habitat risicolo e fauna. Bologna: Bayer Crop Science Script Editore.

Buhl, H.U., Fridgen, G., \& Hackenbroch, W. (2009). An Economic Analysis of Service-Oriented Infrastructures for Risk/Return Management. In Proceedings of the 17th European Conference on Information Systems (ECIS), Verona, Italy. pp. 2060-2072.

Capitanio, F., Adinolfi, F., \& Di Pasquale, J. (2016). The income stabilization tool: Assessing the hypothesis of a national mutual fund in Italy. American Journal of Applied Sciences, 13(4), 357363. Doi: 10.3844/ajassp.2016.357.363.

Castañeda-Vera, A., \& Garrido, A. (2017). Evaluation of risk management tools for stabilising farm income under CAP 2014-2020. Economia Agraria y Recursos Naturales, 17(1), 3-23. doi: 10.7201/earn.2017.01.01.

Le Clech, N., \& Fillat-Castejón, C. (2017). International aggregate agricultural supply for grain and oilseed: The effects of efficiency and technological change. Agribusiness, 33(4), 569-585. doi: 10.1002/agr.21514.

Coble, K.H., Zuniga, M., \& Heifner, H. (2003). Evaluation of the interaction of risk management tools for cotton and soybeans. Agricultural Systems, 75(2-3), 323-340. doi: 10.1016/S0308$521 \times(02) 00073-2$.

Dawe, D. (2010). The Rice Crisis: Markets, Policies and Food Security. Eedited by D. Dawe. 1st ed., FAO and Earthscan.

Deng, X., B.J. Barnett, \& Vedenov, D. V. (2007). IsThere a Viable Market for Area-Based Croplnsurance?' American Journal of AgriculturalEconomics, 89, 508-519.

Dick, W.J.A., \& Wang, W. (2010). Government interventions in agricultural insurance. Agriculture and Agricultural Science Procedia, 1(2010), 4-12. doi: 10.1016/j.aaspro.2010.09.002.

Ente Nazionali Risi (2015). XLVIII Relazione Annuale Anno 2015, press realease.

Ente Nazionale Risi (2017). Evoluzione di mercatoe sue prospettive. Roma, 14 dicembre 2017. 
European Commission (2015). EU rice economic fact sheet. European Commission DirectorateGeneral for Agriculture and Rural Development, economics and analysis of agricultural markets.

European Commission (2017). Risk Management schemes in EU agriculture. Dealing with risk and volatility., press realease.

European Commission (2018). Committee for the Common Organisationof Agricultural Markets., press release.

European Commission (2019). Cambodia: EU launches procedure to temporarily suspend trade preferences. press release.

FAO (2018). Rice Market Monitor. April 2018.

Fusi, A., Bacenetti, J., Gonza'lez-Garci'a, S., Vercesi, A., Bocchi, S., \& Fiala, M. (2014). Environmental profile of paddy rice cultivation with different straw management. Science of the Total Environment 494-495, 119-128. doi: 10.1016/j.scitotenv.2014.06.126.

Grinblatt, M., \& Titman, S. (2002). Financial Markets and Corporate Strategy. McGraw-Hill-Irwin.

Hart, C.E., Babcock, B.A., \& Hayes, D.J. (2001). Livestock revenue insurance. Journal of Futures Markets, 21(6), 553-580. doi: 10.1002/fut.1603.

Hau, A. (2006). Production under uncertainty with insurance or hedging. Insurance: Mathematics and Economics, 38(2), 347-359. doi: 10.1016/j.insmatheco.2005.09.006.

He, J., Rejesus, R., Zheng, X., \& Yorobe, J. (2018). Advantageous Selection in Crop Insurance: Theory and Evidence. Journal of Agricultural Economics, 69(3), 646-668. doi: 10.1111/14779552.12267.

Headey, D. (2011). Rethinking the global food crisis: The role of trade shocks. Food Policy, 36(2), 136-146. doi: 10.1016/j.foodpol.2010.10.003. 
Hellerstein, D., Higgins, N., \& Horowitz, J. (2013). The predictive power of risk preference measures for farming decisions. European Review of Agricultural Economics, 40(5), 807-833. doi: 10.1093/erae/jbs043.

Karyotis, C., \& Alijani, S. (2016). Soft commodities and the global financial crisis: Implications for the economy, resources and institutions. Research in International Business and Finance, 37: 350359.

Kornher, L., \& Kalkuhl, M. (2013). Food Price Volatility in Developing Countries and its Determinants. Quarterly Journal of International Agriculture, 52(4), 277-308

Lence, S.H. (2009). Do futures benefit farmers? American Journal of Agricultural Economics, 91(1), 154-167. https://www.jstor.org/stable/20492415.

Machnes, Y., \& Wong, K.P. (2003). A note on deductible insurance and production. GENEVA Papers on Risk and Insurance Theory, 28(1), 73-80.

Mahul, I., \& Vermersch, D. (2000). Hedging crop risk with yield insurance futures and options. European Review of Agricultural Economics, 27(2), 109-126. doi: 10.1093/erae/27.2.109.

Menapace, L., Colson, G., \& Raffaelli, R. (2013). Risk aversion, subjective beliefs, and farmer risk management strategies. American Journal of Agricultural Economics, 95(2), 384-389.

Munich RE. (2011). Crop insurance for the wealthy? Why revenue insurance comes at a price. München.

Olson E., Vivian A. J., \& Wohar M. E. (2014). The relationship between energy and equity markets: Evidence from volatility impulse response functions. Energy Economics, 43(C), 297-305.

Pasaribu, S.M. (2010). Developing rice farm insurance in Indonesia. Agriculture and Agricultural Science Procedia 1, 33-41. doi: 10.1016/j.aaspro.2010.09.005.

Peri, M., Vandone, D., \& Baldi, L. (2014). Internet, noise trading and commodity futures prices. International Review of Economics and Finance, 33(C), 82-89. doi: 10.1016/j.iref.2014.03.006. 
Pinstrup-Anderson, P. (Editor) (2015). Food Price Policy in a era of Market Instability. A political Economic Analysis. Oxford: Oxford University Press.

Rezitis, A.N., Ntinou, A.G., \& Pachis, D.N. (2015). Investigating the international prices of wheat and rice. Agricultural and Food Economics, 3(1), 3-16. doi: 10.1186/s40100-015-0035-4.

Santeramo, F.G. (2018). Imperfect information and participation in insurance markets: evidence from Italy. Agricultural Finance Review, 78(2), 183-194. doi: 10.1016/j.jpubeco.2016.03.006.

Santeramo, F.G., \& Ford Ramsey, A. (2017). Crop Insurance in the EU: Lessons and Caution from the US. EuroChoices, 16(3), 34-39. doi: 10.1111/1746-692X.12154.

Santeramo, F.G., Goodwin, B.K., Adinolfi F., \& Capitanio, F. (2016). Farmer Participation, Entry and Exit Decisions in the Italian Crop Insurance Programme. Journal of Agricultural Economics, 67(3), 639-657. doi: 10.1111/1477-9552.12155.

Severini, S., Biagini L., \& Finger, R. (2018). Modeling agricultural risk management policies - The implementation of the Income Stabilization Tool in Italy. Journal of Policy Modeling, 41(1), $140-$ 155. doi: 10.1016/j.jpolmod.2018.03.003.

Tang, S., Wang, Y., \& Hui, X. (2010). An empirical study of agricultural insurance-evidence from China. Agriculture and Agricultural Science Procedia, 1(2010), 62-66. doi: 10.1016/j.aaspro.2010.09.008.

Tomek, W., \& Kaiser, H. (2014). Agricultural product prices. 5th ed. Cornell University Press.

Turvey, C. (1989). Evaluating premiums for a farm income insurance policy. Canadian Journal of Agricultural Economics, 37(2), 233-247. doi: 10.1111/j.1744-7976.1989.tb03348.x.

Williams, C., \& Smith, M. (1997). Risk management and insurance. 8th ed. McGraw Hill.

Wolf, C. (2012). Dairy farmer use of price risk management tools. Journal of Dairy Science, 95(7), 4176-4183. doi: 10.3168/jds.2011-5219. 
World Bank (2014). Myanmar - Rice price reduction and poverty reduction. Washington DC: World Bank Group. http://documents.worldbank.org/curated/en/510031468287383757/MyanmarRice-price-reduction-and-poverty-reduction 
Figure 1

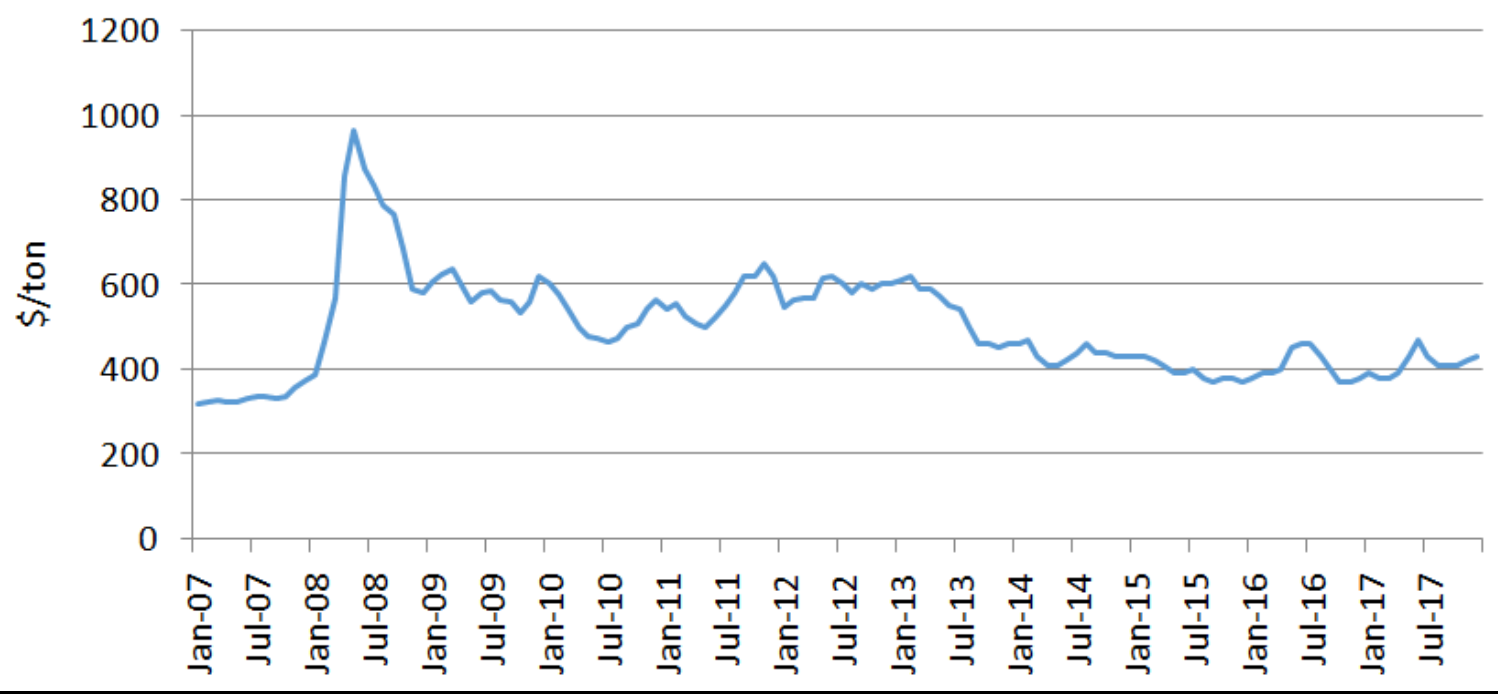

Figure 1: Price trend at world level.

Source: Jackson Son \& Co. data (f.o.b. Bangkok, White Rice, Thai 100\% B second grade)

Figure 2 and 3

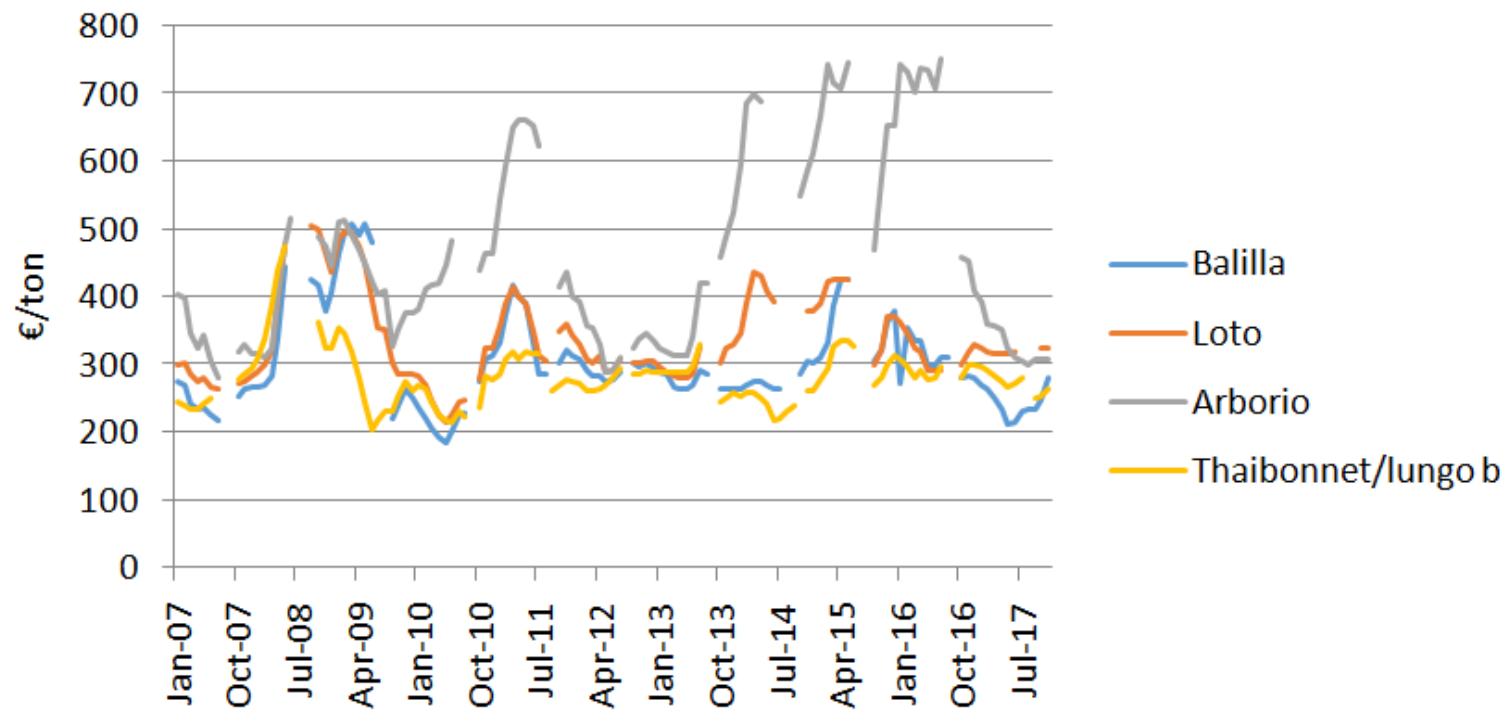

Figure 2. Price trend in Italy for paddy rice.

Source: Chamber of commerce of Vercelli data 


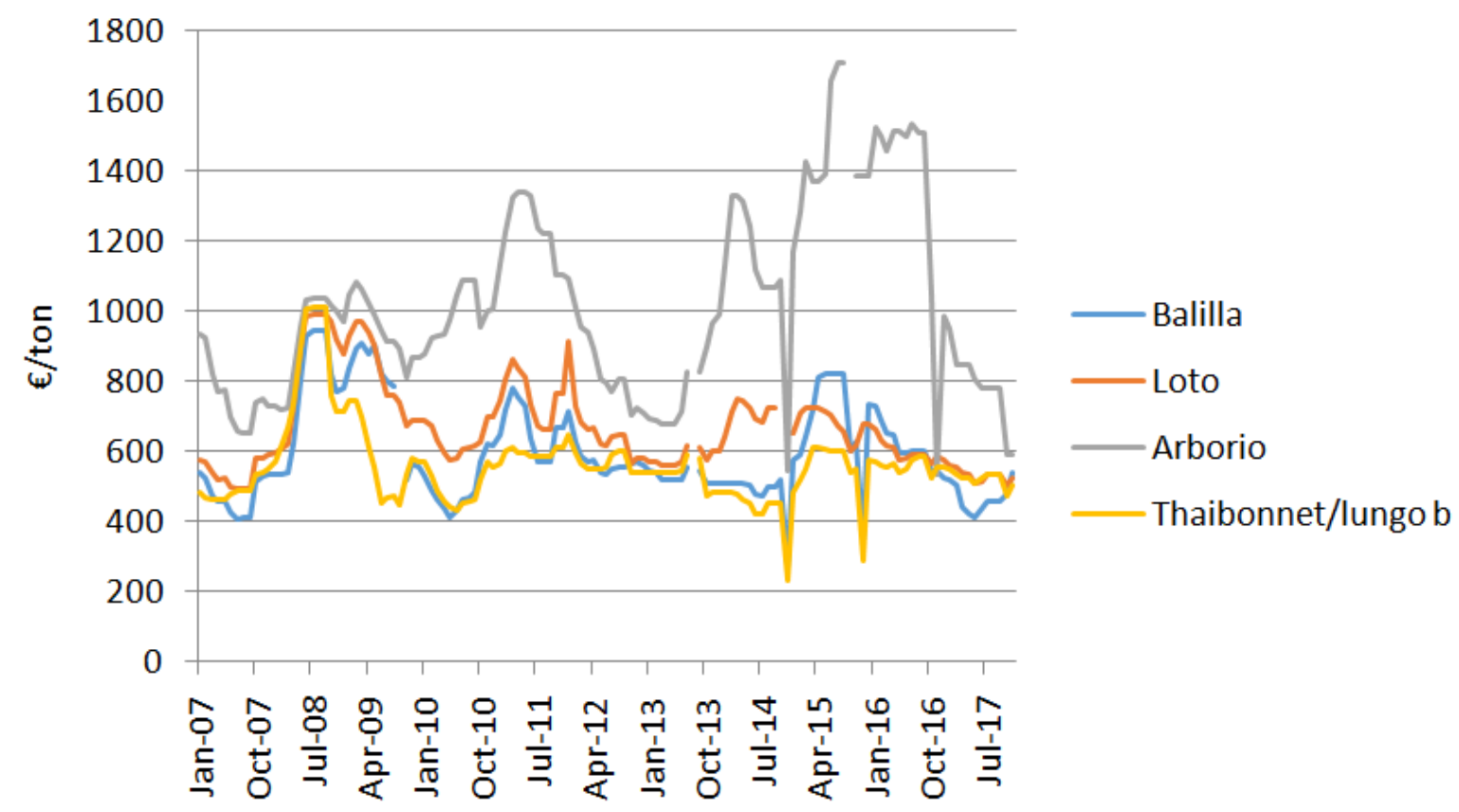

Figure 3. Price trend in Italy for milled rice.

Source: Chamber of commerce of Vercelli data

Figure 4

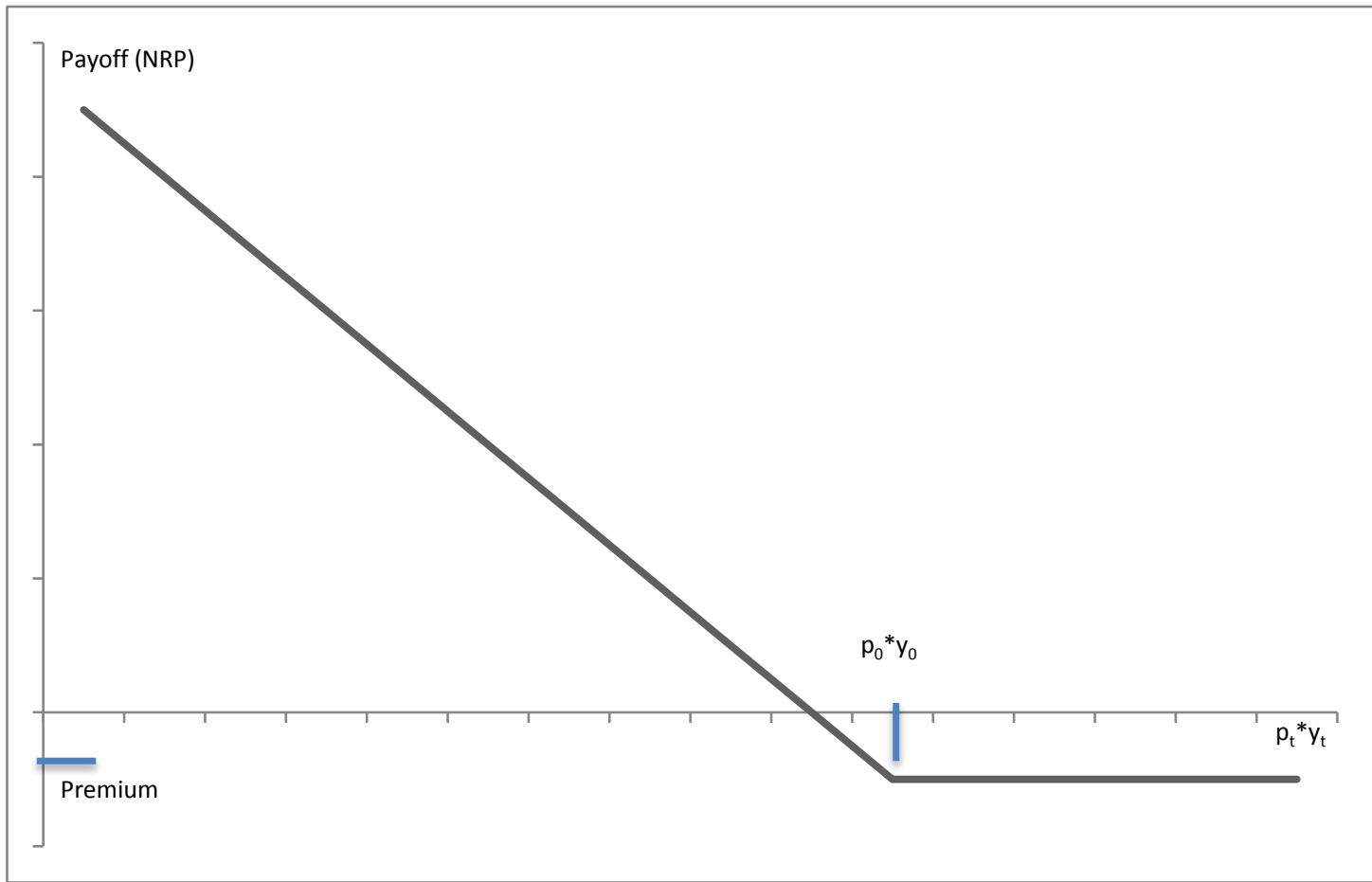

Figure 4.The payoff (NRP). 